\title{
ANNUAL VARIATIONS IN FISH FECUNDITY
}

\author{
By T. B. Bagenal \\ The Marine Station, Millport
}

The variation in the fecundity of a fish species from year to year has not received much attention, although the changes in the numbers of young fish in the plankton are well documented for the Plymouth area (Russell 1930-47; Corbin, 1948-51). The most important work considering fecundity fluctuations is that of Simpson (195I) who, working on Plaice, Pleuronectes platessa L., concluded that during 1947,1948 and 1949 there was a steady decrease in the number of eggs laid, this being due to a decrease in the mean size of the spawning fish which he showed to be correlated with the egg numbers. Simpson's interest in the fecundity was to provide a more accurate estimate for determining the number of plaice in the total population from planktonic egg surveys similar to the work of Buchanan-Wollaston (1923). He did not consider in detail whether the fecundity for a given length might change from year to year. It is this problem which will be considered here. Estimates of fecundity of Long Rough Dabs, Hippoglossoides platessoides (Fabr.), will be analysed, and Simpson's Plaice data will also be considered.

\section{MATERIAL AND METHODS}

The fecundity of the fish is defined, for the purposes of this paper, as the number of eggs in the ovary before spawning.

The data for Plaice are taken from the admirably complete appendix I given by Simpson (195I), where full details are presented for Plaice caught in the North Sea Southern Bight during 1947/48 and 1948/49.

The data for Long Rough Dabs for 1954 are given in table 30, appendix 4, of Bagenal (1957) and for 1955 and 1956 in the Appendix of this paper (p. 382). The details of sampling methods and subsequent laboratory treatment of the fish, together with particulars of the storage, subsampling, counting of the eggs and statistical analysis are all given in the earlier paper (Bagenal, 1957).

I would like to thank Miss Sheila Morris who counted the eggs and did much of the computation, my wife for statistical advice and the master and crew of M.V. Calanus who caught the fish.

\section{LONG ROUGH DAB FECUNDITY IN 1954, 1955 AND 1956}

The mean length, weight, age and fecundity are given in Table $I$ for fish caught in 1954,1955 and 1956 , together with the expected weight $(\hat{W})$ of a fish $22 \mathrm{~cm}$ long. $\hat{W}$ has been calculated from the log length-log weight relation 
and may be taken as a measure of the condition of the fish (Le Cren, I95I; Bagenal, 1957).

The expected fecundity $(\hat{F})$ of a $22 \mathrm{~cm}$ Long Rough Dab is also given for each year and has been calculated from the log length-log fecundity relation (Bagenal, I957). The results of the statistical analysis are given in Table 2 and show that the fecundities, even after allowance has been made for the length

TABLE 1. SUMMARY OF DATA GIVEN IN TABLE 5

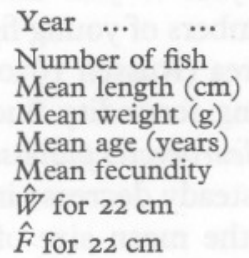

1954
116
$21 \cdot 85$
$72 \cdot 06$
$3 \cdot 2$
90,341
$73 \cdot 65$
92,238

I955
I2
$21 \cdot 04$
$55 \cdot 54$
$4 \cdot 2$
68,292
$64 \cdot 32$
78,468

1956
23
$22 \cdot 70$
$79 \cdot 53$
$3 \cdot 7$
98,339
$71 \cdot 74$
89,193

TABLE 2. ANALYSIS OF COVARIANCE OF LENGTH AND FECUNDITY DATA FOR LONG ROUGH DABS IN 1954, 1955 AND 1956

\begin{tabular}{|c|c|c|c|c|c|}
\hline Source & $\begin{array}{l}\text { Sum of } \\
\text { squares }\end{array}$ & D.F. & $\begin{array}{l}\text { Mean } \\
\text { square }\end{array}$ & $F$ & $\begin{array}{l}\text { Signi- } \\
\text { ficance }\end{array}$ \\
\hline Due to total regression & I9.04358I & I & I9.04358I & $I 466 \cdot I$ & $\star \star$ \\
\hline $\begin{array}{l}\text { Difference between 'means } \\
\text { regression' and 'average } \\
\text { within years regression' }\end{array}$ & 0.034180 & I & 0.034180 & 2.67 & N.S. \\
\hline $\begin{array}{l}\text { Deviations of means about } \\
\text { 'means regression' }\end{array}$ & 0.099176 & $\mathbf{I}$ & 0.099176 & $7 \cdot 75$ & $\star \star$ \\
\hline $\begin{array}{l}\text { Between adjusted } \\
\text { fecundity means }\end{array}$ & 0.133356 & 2 & 0.066678 & $5 \cdot 22$ & $\star \star$ \\
\hline $\begin{array}{l}\text { Between years regression } \\
\text { coefficients }\end{array}$ & 0.043802 & 2 & 0.021901 & $r \cdot 71$ & N.S. \\
\hline $\begin{array}{l}\text { Total deviations about } \\
\text { years regressions }\end{array}$ & $7 \cdot 642091$ & 598 & 0.012779 & 一 & \\
\hline $\begin{array}{l}\text { Average within years } \\
\text { regression }\end{array}$ & $7 \cdot 685893$ & 600 & 0.012801 & 一 & \\
\hline $\begin{array}{l}\text { Deviations about total } \\
\text { regression }\end{array}$ & $7 \cdot 819249$ & 602 & 0.012989 & - & \\
\hline Total & $26 \cdot 862830$ & 603 & 一 & & \\
\hline
\end{tabular}

The degrees of freedom are based on four counts for each fecundity estimate.

differences, differ significantly at the I \% level from year to year. The condition, as shown by expected weights, for fish of $22 \mathrm{~cm}$ is also significantly different over the three years, and it is of interest that the ranked order is the same for condition and fecundity.

The large mean square for the deviations of the means about their regression, when contrasted with the very large mean square due to total regression and the smaller mean square after adjustment to a common length, emphasizes the utility of an analysis of covariance based on all the data. 


\section{PLAICE FECUNDITY IN 1947/48 AND 1948/49}

The fecundity data given by Simpson (I95I) for Southern Bight North Sea Plaice caught in $1947 / 48$ and $1948 / 49$ are summarized in Table 3.

The mean weights are based on the gutted weight minus ovary weight, as with the Long Rough Dabs, and the 'condition' $(\hat{W})$ also applies to somatic tissue only. The mean age is calculated assuming the queried ages Simpson gives were correctly assessed; to ignore the doubtful otolith readings would introduce bias since older fish are the most difficult to age.

TABLE 3. SUMMARY OF SIMPSON'S DATA ON PLAICE FECUNDITY IN THE SOUTHERN BIGHT IN 1947/48 AND 1948/49

$\begin{array}{lcc}\text { Year ... ... } & 1947 / 48 & 1948 / 49 \\ \text { Number of fish } & 169 & 54 \\ \text { Mean length }(\mathrm{cm}) & 37 \cdot 14 & 37 \cdot 08 \\ \text { Mean weight }(\mathrm{g}) & 515 \cdot 21 & 528 \cdot 37 \\ \text { Mean age }(\text { years }) & 7 \cdot 28 & 7 \cdot 17 \\ \text { Mean fecundity } & 84,030 & 87,740 \\ \hat{W} \text { for } 37 \mathrm{~cm} & 509 \cdot 34 & 525 \cdot 20 \\ \hat{F} \text { for } 37 \mathrm{~cm} & 82,996 & 87,152\end{array}$

TABLE 4. ANALYSIS OF COVARIANCE OF REGRESSION OF LOG FECUNDITY ON LOG LENGTH

\begin{tabular}{|c|c|c|c|c|c|}
\hline Source & $\begin{array}{l}\text { Sum of } \\
\text { squares }\end{array}$ & D.F. & $\begin{array}{l}\text { Mean } \\
\text { square }\end{array}$ & $F$ & $\begin{array}{l}\text { Signi- } \\
\text { ficance }\end{array}$ \\
\hline Due to total regression & I6.348027 & I & $16 \cdot 348027$ & $64 \mathrm{I} \cdot 8 \mathrm{O}$ & $\star \star$ \\
\hline $\begin{array}{l}\text { Difference between 'means } \\
\text { regression' and 'average } \\
\text { within years regression' }\end{array}$ & 0.037850 & I & 0.037850 & I. 49 & N.S. \\
\hline $\begin{array}{l}\text { Deviations of means about } \\
\text { 'means regression' }\end{array}$ & - & - & - & - & - \\
\hline $\begin{array}{l}\text { Between adjusted } \\
\text { fecundity means }\end{array}$ & 0.037850 & I & 0.037850 & I.48 & N.S. \\
\hline $\begin{array}{l}\text { Between years regression } \\
\text { coefficients }\end{array}$ & 0.007882 & I & 0.007882 & - & - \\
\hline $\begin{array}{l}\text { Total deviations about } \\
\text { years regressions }\end{array}$ & 5.583633 & 219 & 0.025496 & - & - \\
\hline $\begin{array}{l}\text { Average within years } \\
\text { regression }\end{array}$ & 5.591515 & 220 & 0.025416 & - & - \\
\hline $\begin{array}{l}\text { Deviations about total } \\
\text { regression }\end{array}$ & 5.629365 & 221 & 0.025472 & - & - \\
\hline Total & $21 \cdot 977392$ & 222 & - & - & - \\
\hline
\end{tabular}

The relation of $\log$ fecundity to log length has been re-examined by an analysis of covariance, and the results are given in Table 4. A note arising out of this analysis is given in Appendix 2.

The degrees of freedom are based on one fecundity estimate for each fish.

An examination of Tables 3 and 4 show that the decrease in length in the catches over the two years is barely reflected in the data given by Simpson. The general level of fecundity increased, but this is not statistically significant, and Simpson was justified when he pooled the results for the two years. The weights adjusted to a common length are also not significantly different. 


\section{DISCUSSION}

Simpson was correct in his conclusion that the drop in the mean number of eggs laid per female Plaice in the Southern Bight in 1947, I948 and 1949 was only due to a decrease in the mean size of the spawning fish. The fecundity adjusted to a given length actually increased, though this was not significant over the two years for which data are given. In Long Rough Dabs from the Clyde area, however, significant changes have been found in the fecundity even after allowance has been made for length differences. If population estimates based on fish egg estimates are made over several seasons one cannot necessarily assume that the fecundity-length relation remains constant. An examination of Tables $I$ and 3 shows that fecundity differences cannot be explained by the different age structure of the population.

It may, however, be significant that for the Long Rough Dabs and the Plaice the ranked order of fecundity and condition for the years considered are the same. Within a year (1954) no correlation was found between the condition and fecundity of individual Long Rough Dabs (Bagenal, I957). Comparisons between years and different localities may help to explain some of the enormous variability in fecundity of otherwise apparently similar fish, and a programme of fecundity estimates of a number of species over several years is being initiated at Millport.

\section{REFERENCES}

BAGENAL, M., 1955. A note on the relations of certain parameters following a logarithmic transformation. F. mar. biol. Ass. U.K., Vol. 34, pp. 289-96.

BAgEnAL, T. B., 1957. The breeding and fecundity of the Long Rough Dab Hippoglossoides platessoides (Fabr.) and the associated cycle in condition. F. mar. biol. Ass. U.K., Vol. 36, pp. 339-75.

Buchanan-Wollaston, H. S., I923. The spawning of Plaice in the southern part of the North Sea in 1913-14. Fish Invest. Lond., Ser. 2, Vol. 5, No. 2, 36 pp.

Conbin, P. G., I948-5I. The seasonal abundance of young fish. IX-XI. F. mar. biol. Ass. U.K., Vol. 27, pp. 718-22; Vol. 28, pp. 707-12; Vol. 30, pp. 271-6.

LE CREN, E. D., I95I. The length-weight relation and seasonal cycle in gonad weight and condition in the Perch (Perca fluviatilis). F. Anim. Ecol., Vol. 20, pp. $201-19$.

RUSSELL, F. S., 1930-47. On the seasonal abundance of young fish. I-VIII. F. mar. biol. Ass. U.K., Vol. 16, pp. 707-22; Vol. 20, pp. I47-79 and pp. 595-604; Vol. 21, pp. 679-86; Vol. 22, pp. 493-500; Vol. 23, pp. 38I-6; Vol. 24, pp. 265-70; Vol. 26, pp. 605-8.

Simpson, A. C., I95I. The fecundity of the Plaice. Fish. Invest. Lond., Ser. 2, Vol. 17, No. 5,27 pp. 
APPENDIX 1

TABLE 5. THE LENGTH, WEIGHT, AGE AND EGG COUNTS OF FEMALE LONG ROUGH DABS

\begin{tabular}{|c|c|c|c|c|c|c|c|c|}
\hline \multirow[b]{2}{*}{$\begin{array}{l}\text { Fish } \\
\text { no. }\end{array}$} & \multirow{2}{*}{$\begin{array}{l}\text { Total } \\
\text { length } \\
(\mathrm{cm})\end{array}$} & \multirow[b]{2}{*}{$\begin{array}{l}\text { Weight } \\
\text { (g) }\end{array}$} & \multirow[b]{2}{*}{$\begin{array}{c}\text { Age } \\
\text { (years) }\end{array}$} & \multicolumn{4}{|c|}{ Egg count } & \multirow[b]{2}{*}{$\begin{array}{l}\text { Fecundity } \\
\text { estimates }\end{array}$} \\
\hline & & & & I & 2 & 3 & 4 & \\
\hline \multicolumn{9}{|c|}{ I6 March 1955} \\
\hline 2017 & 25.5 & $98 \cdot 0$ & 4 & 583 & 646 & 704 & 603 & I 26,800 \\
\hline 2019 & 20.0 & $52 \cdot 5$ & 4 & 356 & 330 & $35^{8}$ & 384 & 71,400 \\
\hline 2020 & 20.5 & $5 \mathrm{I} \cdot 5$ & 4 & 313 & 301 & 271 & 305 & 59,500 \\
\hline 2021 & $20 \cdot 5$ & $55^{\circ} 0$ & 4 & 396 & 395 & 405 & $32 \mathrm{I}$ & 75,850 \\
\hline 2022 & $2 I \cdot 0$ & $46 \cdot 5$ & 4 & 207 & 225 & I9I & 234 & 42,850 \\
\hline 2039 & 24.5 & 86.5 & 5 & 273 & 288 & 283 & 277 & 56,050 \\
\hline 2040 & $17 \cdot 0$ & $26 \cdot 5$ & 3 & I 42 & I86 & I7I & I77 & 33,800 \\
\hline 2075 & $22 \cdot 0$ & $63 \cdot 5$ & 4 & 604 & 574 & 605 & $5 \mathrm{I} 4$ & I I 4,850 \\
\hline 2076 & 19.5 & $36 \cdot 5$ & 5 & 243 & 189 & $27 \mathrm{I}$ & 235 & 46,900 \\
\hline 2077 & 19.5 & $360^{\circ}$ & 4 & 343 & 326 & 346 & 332 & 67,350 \\
\hline 2082 & 23.0 & $72 \cdot 5$ & 5 & 448 & 469 & 367 & 384 & 83,400 \\
\hline 2083 & 19.5 & $4 I \cdot 5$ & 4 & 190 & 223 & 199 & 203 & 40,750 \\
\hline \multicolumn{9}{|c|}{22 February 1956} \\
\hline I & $17 \cdot 0$ & 25.5 & 3 & I58 & 204 & I 57 & I58 & 33,850 \\
\hline 2 & $18 \cdot 0$ & 33.5 & 3 & 231 & 275 & 234 & I 86 & 46,300 \\
\hline 3 & 19.0 & 38.5 & 2 & 241 & 250 & 239 & 234 & 48,200 \\
\hline 4 & 19.5 & 44.5 & 3 & 289 & 316 & 296 & 279 & 59,000 \\
\hline 5 & 20.5 & $58 \cdot 5$ & 3 & 376 & 315 & 372 & 340 & 70,150 \\
\hline 6 & $22 \cdot 0$ & 76.0 & 3 & 429 & 449 & 440 & 396 & 85,700 \\
\hline 7 & $22 \cdot 0$ & 70.5 & 4 & 392 & 349 & 368 & 408 & 75,850 \\
\hline 8 & 23.5 & $87^{\circ} \circ$ & 3 & 589 & 601 & 565 & 577 & I 16,600 \\
\hline 9 & $23 \cdot 5$ & $96 \cdot 0$ & 3 & 716 & 709 & 704 & 759 & 144,400 \\
\hline IO & $25 \cdot 5$ & 103.0 & 4 & 629 & 676 & 721 & 636 & 133,100 \\
\hline II & $26 \cdot 0$ & 110.0 & 4 & 760 & 790 & 694 & 835 & I 53,950 \\
\hline 12 & $27 \cdot 5$ & $15 \mathrm{I} \cdot 0$ & 5 & $95^{8}$ & 906 & 850 & 842 & I 77,800 \\
\hline 13 & 23.0 & $77 \cdot 0$ & 4 & 362 & 438 & 482 & 368 & 82,500 \\
\hline 14 & $22 \cdot 5$ & $68 \cdot 5$ & 5 & 518 & $42 I$ & 516 & 478 & 96,650 \\
\hline I5 & $22 \cdot 5$ & $67 \cdot 5$ & 4 & 328 & 308 & 346 & 252 & 61,700 \\
\hline 16 & $20 \cdot 5$ & $48 \cdot 0$ & 4 & 349 & 383 & $3^{8} 3$ & 470 & 79,250 \\
\hline I7 & $20 \cdot 5$ & $45^{\circ} 0$ & 4 & 270 & 304 & 270 & 315 & 57,950 \\
\hline I8 & 24.0 & $8 I \cdot 0$ & 5 & 396 & 350 & 329 & 428 & 75,150 \\
\hline 19 & $24 \cdot 5$ & $92 \cdot 0$ & 4 & 424 & 394 & 524 & 452 & 89,700 \\
\hline 20 & 24.0 & 94.0 & 3 & 586 & 657 & 594 & 539 & I I 8,800 \\
\hline 21 & 25.0 & II 7.0 & 4 & 927 & 939 & 1089 & 922 & 193,850 \\
\hline 22 & 25.5 & 113.5 & 3 & $4 \mathrm{II}$ & 427 & 437 & 545 & 91,000 \\
\hline 23 & 26.0 & $13 \mathrm{I} \cdot 0$ & 4 & 896 & 762 & 806 & 943 & 170,350 \\
\hline
\end{tabular}

\section{APPENDIX 2}

In the analysis of the data the values of fecundity and length were transformed to their logarithms in order to produce a linear relation and to use the standard methods of regression analysis. An interesting point which emerges from the transformation of Simpson's North Sea Southern Bight data is that the geometric mean fecundity is larger for 1947/48, whereas the arithmetic mean fecundity is greater for the $1948 / 49$ winter. The figures are summarized in Table 6. Had the differences between the means for the two seasons been significant, it might have appeared from the analysis that this was a decrease 
and not an increase. The reason for this anomaly can be seen from the relation between the arithmetic and geometric means for a normal distribution which has been given by Bagenal (1955) and may be written

$$
\text { G.M. }=\text { A.M. } /\left(I+\sigma^{2} / \text { A.M. }^{2}\right)^{\frac{1}{2}},
$$

where A.M. and G.M. are the arithmetic and geometric means and $\sigma^{2}$ is the variance. This gives for $1947 / 48$ calculated G.M. $=72,458$; for $1948 / 49 \mathrm{calcu}-$ lated G.M. $=67,126$. The discrepancy between the actual and calculated geometric means is probably due to the data not being normally distributed, which is shown by the difference between the range and $6 \sigma$ (Table 6).

TABLE 6. SUMMARY OF FECUNDITY STATISTICS FOR SOUTHERN BIGHT PLAICE

\begin{tabular}{lrr} 
& \multicolumn{1}{c}{$\mathrm{I} 947 / 48$} & \multicolumn{1}{c}{$1948 / 49$} \\
Arithmetic mean fecundity & 84,030 & 87,740 \\
Variance $\left(\sigma^{2}\right)$ & $2,439,500,000$ & $6,764,600,000$ \\
Range & 332,000 & 280,000 \\
$6 \sigma$ & 296,316 & 493,500 \\
Mean log fecundity & $4 \cdot 8317$ & 4.7916 \\
Geometric mean & 67,874 & $6 \mathrm{I}, 888$
\end{tabular}

It is clear that the difference between the ranked order of the arithmetic and geometric means of the two sets of plaice fecundity data is due to the large difference between the variances. 